more than a dozen additions have been made to it, each perpetuating the name of a benefactor and each making its own contribution to the advancement of knowledge.

\section{Tradition of Examining}

To the general public the College is best known as an examining body. In this function it works beside the other two corporations, and it was a symbol of the new era that in 1886 Queen Victoria in person opened the old Examination Hall on the Embankment. Examining may seem a humdrum activity. Anyone, indeed, can see that the decision whether a candidate shall practise medicine or not is momentous for him and still more momentous for his potential patients. But few people remember that just and competent examining is one of the vital necessities of our educational system, and no one has ever written the history of examining. If ever that history is written it will give a place of honour to the College. Ever since its foundation it has built up its tradition of examining, sometimes in the face of opposition, and at least once in the face of danger. In the time of George III a rejected applicant for a licence challenged the senior censor to a duel. It was beneath the censorial dignity to fight, but there was a sequel in the law courts, when the challenger was found guilty of criminal libel. It may be surprising but it is actually characteristic of the
College, even in those days, which were not its best days by any means, that in the end it examined the man again and magnanimously admitted him as a licentiate.

That is a trifling incident from the long history of how the College built up its tradition. The period of medical reform interrupted the continuity of its work in many particulars. Several of its functions were assigned to newly created specialized bodies, whether directly or indirectly under the control of the State, employing full-time staffs, both medical and lay, to do work which the busy physicians of the College had done voluntarily. But through all these changes the tradition of the College remained, constantly replenishing a reserve of authority which has enabled it in our own time to intervene decisively in great medical questions. The tradition is indeed far older than the College ; it was as guardians of the tradition that Linacre and his companions created the College. It has always had two sides, on the one hand to safeguard the status of the physician and on the other to insist that this status implies obligations. No one will pretend that the College was always right in its interpretation of either one side or the other. There were times when it was too rigid, times when it was too exclusive, times when it was regrettably inactive. But the high claim may be made for it that in no single one of its quarrels, whatever the immediate issue may have been, did it take its stand on the lower of two opposing concepts of the physician's art or of his place in society.

\title{
Post-operative Renal Function in Obstructive Jaundice : Effect of a Mannitol Diuresis
}

\author{
J. L. DAWSON,* M.S., F.R.C.S.
}

Brit. med. F., 1965, 1, 82-86

Obstructive jaundice predisposes to acute post-operative renal failure (Clairmont and Von Haberer, 1911; Aird, 1953; Zollinger and Williams, 1956 ; Dawson, 1964a). Investigations were therefore planned to see whether the presence of obstructive jaundice predisposes to any minor post-operative changes in renal function which might indicate the possible mechanism of this renal failure.

Daily sequential renal function studies were made on 15 jaundiced patients before and after operation. The results were compared with those obtained from a group of 12 non-jaundiced patients undergoing operations of similar magnitude.

As animal experiments have demonstrated, a mannitol diuresis affords a remarkable protective effect against renal anoxia in jaundice (Dawson, 1964a). Pre-operative and postoperative renal function studies were made in a further seven jaundiced patients in whom a mannitol diuresis was initiated just before operation and maintained for two to three days afterwards.

\section{Methods}

Pre-operative Observations.-A physical examination was carried out on all patients, with special reference to their height, weight, blood-pressure, and general physical state. Estimations of haemoglobin and packed-cell volume, blood-urea level, a

* Senior Surgical Registrar, King's College Hospital, London. Present address: Harvard Surgical Unit, Bos 24-hour endogenous creatinine clearance, and the specific gravity, volume, and sodium concentration of each 24-hour urine specimen were carried out two to three days before operation. The creatinine levels were estimated on an AutoAnalyzer using the Jaffe reaction. A mid-stream specimen of urine in males and a clean specimen of urine in females were centrifuged and the deposit examined under a microscope. In jaundiced patients the serum-bilirubin level, prothrombin time, serumprotein level, and the zinc and thymol turbidity tests were done within two days of operation. All the creatinine-clearance levels have been corrected to the value for a body surface area of 1.73 sq. $\mathrm{m}$.

Observations during Operation.-The following observations were made: the length of the operation, the anaesthetic drugs used, regular blood-pressure recordings (at 10-minute intervals), and the blood loss by weighing the swabs. An exact record of the operative procedure carried out was also made.

Post-operative Observations.-Blood and urine specimens were collected each morning and the patient's blood-pressure and general condition noted. Daily observations for seven to ten days were made of 24-hour urine volumes, urine specific gravity, urine sodium concentration, 24-hour endogenous creatinine clearance, blood urea, haemoglobin, and packed-cell volume. A daily serum bilirubin was estimated in the jaundiced patients. In all patients $10 \mathrm{ml}$. of fresh urine was centrifuged daily and the deposit examined under a microscope. The first post-operative collection period was usually under 24 hours unless the patient had failed to pass urine by 8.30 a.m., when the collection was extended to the next morning. 
Mannitol Infusions.-Pre-operative and post-operative creatinine-clearance levels were measured in a further seven patients with obstructive jaundice in whom a mannitol diuresis was established 24 hours before operation and maintained for two days afterwards. Collections were made for the first four postoperative days. Two pre-operative estimates were made in five out of seven patients and the mean levels used in calculations. One bottle $(540 \mathrm{ml}$.) of mannitol $(10 \%)$ was infused, beginning two hours before operation. After the operation one or two bottles of mannitol ( $5 \%$ ) were infused in each 24 -hour period to maintain the urine output at over $1 \mathrm{ml} . / \mathrm{min}$.

\section{Results}

The detailed results of each individual patient are not given. Only the salient features are presented and analysed in this section.

The 12 control patients underwent cholecystectomy (some with choledochotomy) or partial gastrectomy. These operations were chosen because the incision used, the handling of viscera, length of operation, etc., were comparable with the usual procedures carried out in a patient with obstructive jaundice.

Seven of the 15 jaundiced patients underwent a by-pass procedure (cholecystenterostomy), two underwent pancreaticoduodenectomy, and the remainder were deemed inoperable, there being no dilated extrahepatic duct to anastomose to the gastro-intestinal tract.

The results of the observations made before and during the surgical treatment of these two groups of patients are summarized and compared in Table I (all results except the urineflows in Tables II and IV are given to the nearest first decimal place), which shows that there is no significant difference between the two groups with respect to pre-operative haemoglobin, pre-operative blood urea, length of operation, and the blood loss measured at operation; nor was there any difference between the anaesthetic drugs used or the fluctuations of bloodpressure during operation, the blood-pressure falling below 90 $\mathrm{mm}$. $\mathrm{Hg}$ in three patients who were not jaundiced and in five patients who were jaundiced.

TABLE I.-Comparison of Pre-operative Investigations in 15 faundiced and 12 Non-faundiced Patients. (Mean and Standard Error of the Mean)

\begin{tabular}{|c|c|c|c|c|c|}
\hline $\begin{array}{c}\text { Pre-operative } \\
\text { Values }\end{array}$ & & $\begin{array}{c}\text { Non- } \\
\text { jaundiced }\end{array}$ & Jaundiced & $t$ value & Probability \\
\hline $\begin{array}{l}\text { Age in years } \\
\text { Haemoglobin (\%) } \\
\text { Systolic B.P. (mm.Hg) } \\
\text { Blood urea (mg./ml.) } \\
\text { Creat. clear. (ml./min.) } \\
\text { Length of op. (mins.) } \\
\text { Blood loss at op. (ml.) }\end{array}$ & $\begin{array}{l}\ldots \\
\cdots \\
\cdots \\
\cdots \\
\cdots\end{array}$ & $\begin{array}{l}54 \cdot 3 \pm 5 \cdot 0 \\
93 \cdot 8 \pm 9 \cdot 1 \\
148 \pm 8 \cdot 1 \\
26 \cdot 5 \pm 1 \cdot 6 \\
63 \cdot 8 \pm 7 \cdot 8 \\
95 \cdot 8 \pm 8 \cdot 5 \\
187 \pm 55 \cdot 8\end{array}$ & $\begin{array}{l}66 \cdot 9 \pm 2 \cdot 7 \\
87 \cdot 1 \pm 7 \cdot 9 \\
173 \pm 7 \cdot 5 \\
27 \cdot 3 \pm 1 \cdot 4 \\
92 \cdot 7 \pm 8 \cdot 2 \\
86 \cdot 3 \pm 12 \cdot 7 \\
164 \pm 58 \cdot 4\end{array}$ & $\begin{array}{l}\frac{2 \cdot 33}{2 \cdot 33} \\
\frac{2 \cdot 48}{-} \\
-\end{array}$ & $\begin{array}{l}<0.05 \\
\text { Not sig. } \\
<0.05 \\
\text { Not sig. } \\
<0.02 \\
\text { Not sig. } \\
\text { Not sig. }\end{array}$ \\
\hline
\end{tabular}

On the other hand, the mean pre-operative systolic bloodpressure in $\mathrm{mm}$. $\mathrm{Hg}$ is significantly higher in the jaundiced patients $\left(173 \pm 7.5^{1}\right)$ than in the patients who were not jaundiced $(148 \pm 8.1)$; the mean age in years of the jaundiced patients is also significantly greater-66.9 \pm 2.7 compared with $54.3-5.0$. Yet in spite of this the mean pre-operative creatinine clearance level $(\mathrm{ml} . / \mathrm{min}$.) is significantly higher in the jaundiced patients $(\mathrm{P}<0.02)$. This difference is almost certainly due to a sampling error.

\section{Post-operative Observations}

In the first three post-operative days the creatinine clearance levels fell below the pre-operative values in all patients, except two of those who were not jaundiced (see Fig. 2). The amount of this fall was significantly greater in the jaundiced patients, whether the results were expressed as an absolute drop (ml./

${ }^{1}$ Mean and standard error of the mean. min.) or as a percentage of the pre-operative testing level $(\mathrm{P}<0.02$, see Table II). There was no significant difference in the urine flows in the two groups over the period of maximum fall in creatinine clearance. There was no significant difference in the results of the other post-operative observations, which are compared in Table II.

TABLE II.-Comparison of Post-operative Observations Made in 15 faundiced and 12 Non-jaundiced Patients. (Mean and Standard Error of the Mean)

\begin{tabular}{|c|c|c|c|c|}
\hline $\begin{array}{c}\text { Post-operative } \\
\text { Observation }\end{array}$ & $\begin{array}{c}\text { Non- } \\
\text { jaundiced }\end{array}$ & Jaundiced & $\mathrm{t}$ Value & Probability \\
\hline $\begin{array}{l}\text { Max. absolute drop in } \\
\text { creat. clear. (ml./min.) } \\
\text { Max. drop in creat. clear. } \\
\text { as \% of pre-op. level } \\
\text { Urine flow in ml./min. over } \\
\text { period max. fall } \\
\text { Min. Na }{ }^{+} \text {conc. in 1st } 3 \\
\text { post-op. days (mEq./1.) } \\
\text { Max. S.G. urine in 1st } 3 \\
\text { post-op. days .. }\end{array}$ & $\begin{array}{c}22 \cdot 9 \pm 7 \cdot 7 \\
31 \cdot 1 \pm 9 \cdot 8 \\
0 \cdot 26 \pm 0 \cdot 03 \\
26 \cdot 1 \pm 5 \cdot 1 \\
1,022 \pm 1 \cdot 7\end{array}$ & $\begin{array}{c}56 \cdot 5 \pm 7 \cdot 4 \\
62 \cdot 8 \pm 6 \cdot 2 \\
0 \cdot 33 \pm 0 \cdot 09 \\
18 \cdot 5 \pm 4 \cdot 3 \\
1,021 \pm 1 \cdot 6\end{array}$ & $\begin{array}{l}3 \cdot 12 \\
2 \cdot 73 \\
0.598 \\
1.26 \\
-\end{array}$ & $\begin{array}{l}<0.01 \\
<0.02 \\
>0.5 \\
>0.2 \\
\text { Not sig. }\end{array}$ \\
\hline
\end{tabular}

It is unlikely that the greater drop in post-operative creatinine-clearance levels in the jaundiced patients is explained by the difference in age of the two groups. No correlation was found between age and percentage drop in creatinine clearance in the two groups (correlation coefficient $r=-0.403, P>0.6$, and $\mathbf{r}=0.21, \mathrm{P}>0.3$ in the non-jaundiced and jaundiced groups respectively). Nor is the difference in post-operative fall in creatinine clearance accounted for by the difference in the blood-pressure of the two groups. When the drop in creatinine clearance observed in patients with systolic bloodpressures above and below $150 \mathrm{~mm}$. $\mathrm{Hg}$ were compared there was no significant difference among the non-jaundiced patients $(P>0.3)$ or among the jaundiced patients $(P>0.2)$.

In contrast there was a strong correlation between the preoperative serum bilirubin and the percentage of post-operative fall in creatinine clearance $(r=0.78, P<0.01$, Fig. 1). The higher the serum bilirubin the greater the post-operative fall in creatinine clearance, which strongly suggests that the presence

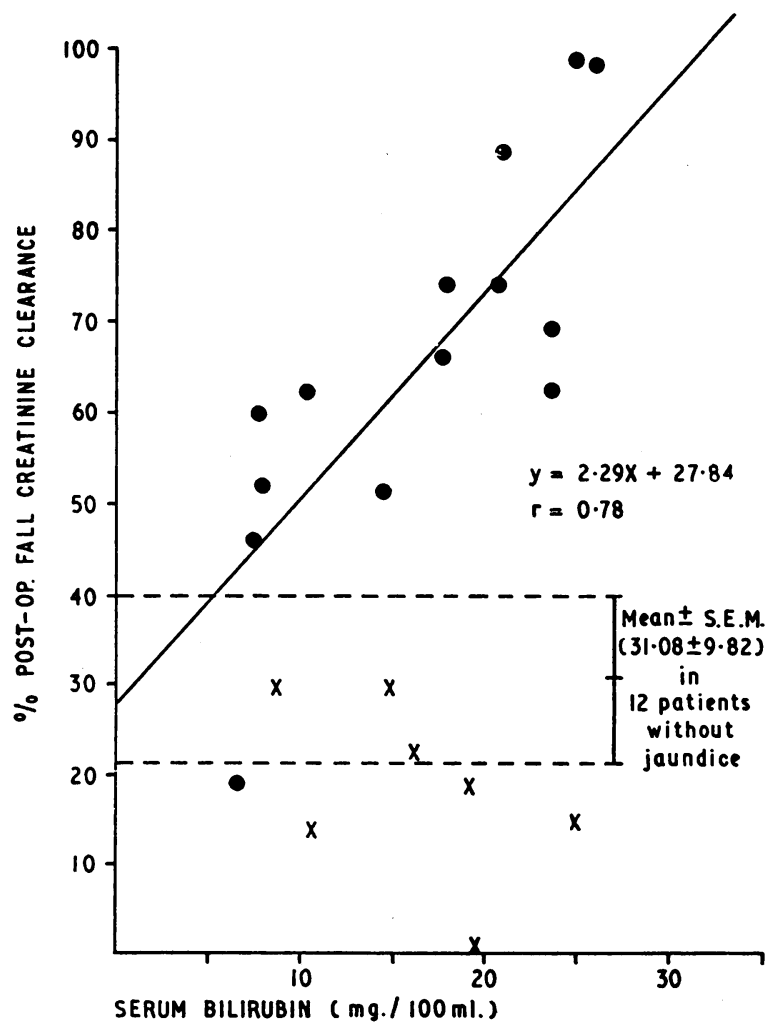
FIG. 1.- Correlation between serum bilirubin and the percentage post-
operative fall in creatinine clearance. $(\Theta=$ Jaundiced patient ; $x=$ Jaundiced patient given mannitol.) 
of obstructive jaundice is the factor responsible for the difference between the jaundiced and non-jaundiced patients.

When the regression line $(r=0.78)$ is drawn (Fig. 1) it is of great interest that the intercept of the ordinate with the regression line-that is, at normal bilirubin values-lies between $28 \%$ and $29 \%$ drop in creatinine clearance ; this is well within the mean and standard error of the mean found in the 12 patients who were not jaundiced $(31.1 \pm 9.9)$. One of the 15 jaundiced patients was not included in the calculation of the correlation coefficient $(r)$ because, unlike all the other patients, he did not have any intraperitoneal manipulation. Immediately the peritoneum was opened the liver was riddled with secondary deposits presented in the wound. A small biopsy specimen was taken and the abdomen immediately closed. The operation lasted less than 25 minutes.

Traces of protein were found in the urine of many patients from day to day. Daily microscopical examinations of the urine in each patient were all normal, excepting for two of the jaundiced patients who developed anuria, in whom numerous granular casts were found. Considerable amounts of protein were found in the urine of these two patients, especially on the day before death. The post-operative blood-pressure recordings showed no significant fluctuations.

Fig. 2 shows the complete results obtained in one of the 15 jaundiced patients who underwent a cholecystoduodenostomy for obstructive jaundice secondary to a small carcinoma of the ampulla of Vater. This was later successfully resected at a second operation. The immediate fall in the creatinineclearance level is characteristic, as is the rise in total creatinine

URINE VOLUME and SPECIFIC GRAVITY

$1 . / 24 \mathrm{hr}$

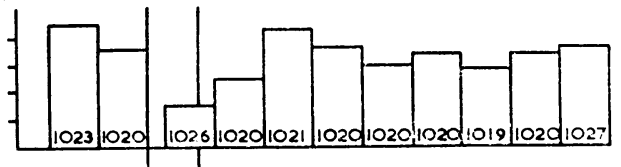

URINE CREATININE ( $9 . / 24 \mathrm{hr}$ ) and SERUM CREATINIHE ( $\mathrm{mg} . / \mathrm{iOOml}$.)

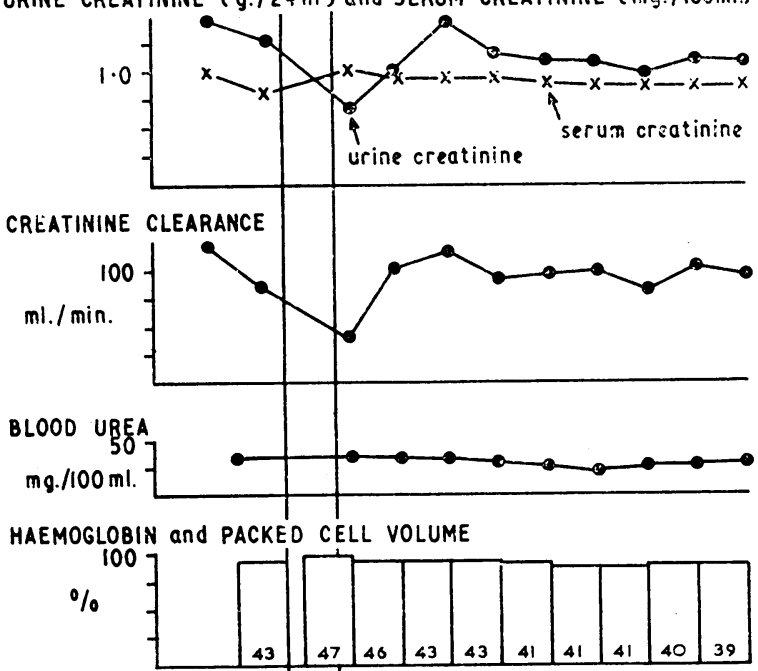

SERUM BILIRUBIH

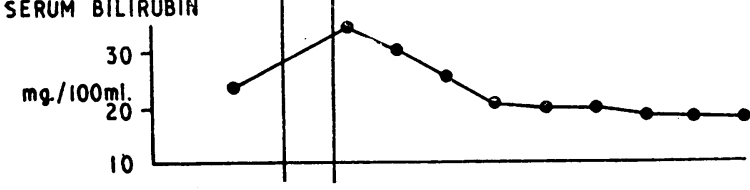

URINE SODIUM CONCENTRATION

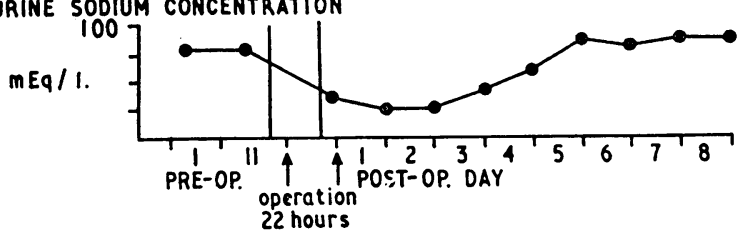

FIG. 2.-Results of observations made on a 64-year-old male patient undergoing cholecystoduodenostomy for the relief of obstructive jaundice due to a small carcinoma of the ampulla of Vater. excretion on the third day. The serum levels remained virtually unchanged.

\section{Effect of a Mannitol Diuresis}

In seven jaundiced patients in whom a mannitol diuresis was established the expected excessive post-operative fall in creatinine clearance was prevented (Fig. 1; patients given mannitol denoted by $X$ ).

These seven patients are compared with the other 15 jaundiced patients with respect to age, blood-pressure, bloodurea levels, creatinine-clearance levels, the pre-operative serumbilirubin levels, length of operation, and blood loss sustained at operation (Table III). This shows that there is no significant difference between the two groups with respect to pre-operative blood-pressure, blood urea, the pre-operative serum-bilirubin levels, pre-operative creatinine-clearance levels, length of operation, and the blood loss. Although the seven patients receiving mannitol were significantly younger $(P<0.05)$, this factor was previously found to have no correlation with the post-operative fall in creatinine clearance (see above).

A comparison of the post-operative urine flow rates, maximum specific gravity in the first three post-operative days, and the post-operative fall in creatinine clearance (absolute and percentage) is shown in Table IV. It will be seen that only the post-operative specific gravity levels are comparable. There is a significant difference in the urine flow rates, the absolute fall in creatinine-clearance levels, and the percentage fall in postoperative creatinine-clearance levels $(\mathrm{P}<0.001, \mathrm{P}<0.01$, and $\mathrm{P}<0.001$ respectively).

The difference in the urine flow rates is the result of the osmotic diuresis produced by mannitol. The difference between the absolute and percentage fall in creatinine clearance is also almost certainly due to the mannitol diuresis, because the two groups of patients are otherwise comparable (Table III).

In these seven patients who received mannitol no correlation was found between the pre-operative serum-bilirubin level and the percentage post-operative fall in creatinine clearance $(r=-0.502, P>0.4$, see Fig. 1$)$.

\section{Discussion}

The results of these observations strongly suggest that the presence of obstructive jaundice modifies the effect of operation on the kidneys. There is a much greater post-operative fall in

TABLE III.-Comparison of Pre-operative Investigations in the Two Groups of Faundiced Patients; Mannitol Given to One Group. (Mean and Standard Error of the Mean)

\begin{tabular}{|c|c|c|c|c|}
\hline $\begin{array}{l}\text { Pre-operative } \\
\text { Investigation }\end{array}$ & $\stackrel{\text { No }}{\text { Mannitol }}$ & Mannitol & $\mathrm{t}$ value & Probability \\
\hline 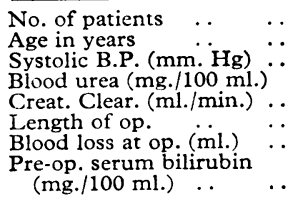 & $\begin{array}{l}\quad 15 \\
66 \cdot 9 \pm 2 \cdot 7 \\
173 \pm 7 \cdot 5 \\
27 \cdot 3 \pm 1 \cdot 4 \\
92 \cdot 7 \pm 8 \cdot 2 \\
86 \cdot 3 \pm 12 \cdot 7 \\
164 \cdot 1 \pm 58 \cdot 4 \\
16 \cdot 6 \pm 1 \cdot 9\end{array}$ & \begin{tabular}{l}
\multicolumn{1}{c}{7} \\
$56 \cdot 3 \pm 4 \cdot 6$ \\
$149 \pm 11 \cdot 3$ \\
$23 \cdot 3 \pm 5 \cdot 1$ \\
$70 \pm 10 \cdot 9$ \\
$113 \pm 16 \cdot 9$ \\
$244 \pm 126$ \\
$16 \cdot 5 \pm 1 \cdot 8$
\end{tabular} & $\begin{array}{l}2.12 \\
1.87 \\
1.15 \\
1.69 \\
1.25 \\
0.21 \\
0.303\end{array}$ & $\begin{array}{l}<0.05 \\
<0.1 \\
>0.2 \\
<0.1 \\
>0.2 \\
>0.8 \\
>0.7\end{array}$ \\
\hline
\end{tabular}

TABLE IV.-Comparison of the Post-operative Investigations in the Two Groups of faundiced Patients, Mannitol Given in One Group. (Mean and Standard Error of the Mean)

\begin{tabular}{|c|c|c|c|c|}
\hline $\begin{array}{l}\text { Post-operative } \\
\text { Observation }\end{array}$ & $\underset{\text { Mannitol }}{\text { No }}$ & Mannitol & $t$ value & Probability \\
\hline $\begin{array}{l}\text { No. of patients } \\
\text { Max. absolute fall in creat. } \\
\text { clear. (ml./min.) } \\
\text { Max. drop in creat. clear. } \\
\% \text { pre-op. (mi./min.) in } \\
\text { Urine flow (ml./m.) } \\
\text { period max. fall } \\
\text { Max. S.G. urine in 1st } 3 \\
\text { post-op. days .. }\end{array}$ & $\begin{array}{c}15 \\
56 \cdot 5 \pm 7 \cdot 4 \\
62 \cdot 8 \pm 6 \cdot 3 \\
0 \cdot 33 \pm 0 \cdot 09 \\
1,021 \pm 1 \cdot 6\end{array}$ & \begin{tabular}{l}
\multicolumn{1}{c}{7} \\
$15 \pm 4 \cdot 1$ \\
$18 \cdot 2 \pm 4 \cdot 1$ \\
$1 \cdot 06 \pm 0 \cdot 18$ \\
$1,024 \pm 1 \cdot 7$
\end{tabular} & $\begin{array}{l}3 \cdot 67 \\
4 \cdot 59 \\
4 \cdot 19 \\
1 \cdot 2\end{array}$ & $\begin{array}{l}<0.01 \\
<0.001 \\
<0.001 \\
>0.2\end{array}$ \\
\hline
\end{tabular}


the creatinine-clearance levels in the jaundiced than in the control patients. The amount of this fall correlates with the pre-operative level of serum bilirubin. The deeper the jaundice the greater the fall. In the seven patients who received mannitol the amount of this fall was much reduced.

Apart from the creatinine clearance the results of the other observations were comparable in the jaundiced and nonjaundiced patient.

The pre-operative creatinine-clearance levels in the jaundiced group $(92.7 \pm 8.2 \mathrm{ml} . / \mathrm{min}$.) were within the normal rangemen, $120 \pm 25.5 \mathrm{ml} . / \mathrm{min}$. ; women, $96+13.5 \mathrm{ml} . / \mathrm{min}$. (Doolan, Alpen, and Theil, 1962). Other workers have found no abnormality of basal renal function in patients with obstructive jaundice, as measured by nitrogen retention, phenolphthalein, or salt-and-water excretion (Abramson, 1926), or para-aminohippurate, inulin, and creatinine-clearance levels (Cattell and Birnstingl, 1964). The values for the 12 control patients are subnormal $(63.8 \pm 7.8 \mathrm{ml} . / \mathrm{min}$.). There is no obvious explanation for this low value other than that it is a sampling error.

After operation the endogenous creatinine-clearance levels fell in all patients, except for two of the control group. The amount of the fall has been expressed in two ways: first, as an absolute drop in $\mathrm{ml} . / \mathrm{min}$., and, second, the absolute drop expressed as a percentage of the pre-operative resting value. This second method of expressing the result is an attempt to circumvent the difficulty that the pre-operative resting values in the two groups are different (Table $I, P<0.02$ ). When the amounts of the absolute drop are compared the difference between the two groups increased (Table II, $\mathrm{t}=3.12, \mathrm{P}<0.01$ ), suggesting that there is a significantly greater fall in the jaundiced patients. On the other hand, it may be argued that because the jaundiced patients began at a higher pre-operative level a bigger absolute drop is expected and is of no real significance.

By expressing the amount of the drop as a percentage of the resting level each patient acts as his own control ; in this way an effort has been made to negate the pre-operative difference between the two groups. When the percentage post-operative fall in the two groups is compared there is a very significant difference (Table II, $\mathrm{P}<0.02$ ).

All the evidence points to the fact that the difference in postoperative fall in creatinine clearance between the jaundiced and control patients is determined by the depth of the jaundice; furthermore, when the regression line is extrapolated through the normal range of serum bilirubin levels (Fig. 1) the predicted fall in creatinine clearance is the same as that actually observed in the 12 control patients. These results suggest that expressing the drop in creatinine clearance as a percentage of the resting value is valid ; they also add some rational understanding to the fact that it is the deeply jaundiced patient who is more likely to develop post-operative anuria (Dawson, 1964b).

Measurement of the endogenous creatinine-clearance level in man is a good guide to the glomerular filtration rate (Steinitz and Türkand, 1940 ; Brod and Sirota, 1948 ; Doolan et al., 1962), although it is not an exact measurement.

A fall in endogenous creatinine clearance almost certainly signifies a decrease in effective renal blood-flow. This is confirmed by animal experiments. A progressive decrease in renal blood-flow has been found experimentally in dogs to cause a decrease in creatinine-clearance levels (Selkurt, Hall, and Spencer, 1949).

The other two theoretical explanations of a fall in endogenous creatinine clearance are efferent arteriole dilatation (reducing the filtration fraction) or tubular reabsorption of creatinine. Efferent arteriole dilatation has not been demonstrated in man (Brod, 1953 ; Robinson, 1954). Tubular reabsorption of creatinine is only a theoretical possibility. In fact, all the known evidence points to the opposite phenomenon of tubular secretion of creatinine (Shannon, 1935 ; Smith, 1943).
Thus unless hitherto unrecognized factors are affecting the creatinine-clearance values in the post-operative period the most likely explanation of the observed post-operative fall is that there is a decrease in effective renal blood-flow. This probably results from a combination of many factors such as the general anaesthesia (Habif, Papper, Fitzpatrick, Lowrance, Smythe, and Bradley, 1951), the trauma of the operation including traction on viscera (De Wardener, 1955), uncompensated oligaemia or metabolic acidosis (Lauson, Bradley, and Cournand, 1944), and pain from the wound.

But these factors were all comparable in the two groups of patients under study; thus the jaundiced patients appear to react more adversely to operation. There is some precedent for this view, because it is much easier to induce hypotension in jaundiced dogs than in control animals (Williams, Elliott, and Zollinger, 1960 ; Cattell and Birnstingl, 1964).

It has recently been shown that renal parenchyma is more easily damaged by anoxia in the presence of obstructive jaundice (Dawson, 1964a). The acute renal failure which follows operation in deeply jaundiced patients appears, therefore, to be a summation of two complementary effects of obstructive jaundice: (1) it increases the sensitivity of the renal parenchyma to anoxia, and (2) it predisposes to a post-operative decrease in effective renal blood-flow.

\section{Effect of a Mannitol Diuresis}

Recently it has been suggested that in acute renal failure there is a stage of disordered function which precedes organic tubular damage (Sevitt, 1959 ; Barry and Malloy, 1962 ; Finckh, 1962) ; the organic damage may be prevented by the use of an osmotic diuretic during the phase of disordered function (Barry and Malloy, 1962 ; Eliahou, 1964). The relevance of these observations has been shown to apply to renal anoxia and jaundice in rats (Dawson and Stirling, 1964).

It has been shown experimentally that a mannitol diuresis, initiated before a period of oligaemia, prevents or decreases the expected fall in effective renal blood-flow (Braun and Lilienfield, 1962). A similar protective effect was observed in these seven patients with obstructive jaundice who were given mannitol ; the post-operative decrease in effective renal blood-flow was largely prevented (see Fig. 1). As this post-operative decrease in effective renal blood-flow is probably an important contributing factor in the genesis of acute tubular necrosis, it seems advisable to give all deeply jaundiced patients prophylactic mannitol before operation.

\section{Summary}

Sequential renal-function studies were performed in 12 control and 15 jaundiced patients.

There was a significantly greater post-operative fall in creatinine clearance in the jaundiced patients.

There was a highly significant correlation between the preoperative serum-bilirubin level and the percentage post-operative fall in creatinine clearance $(r=0.78)$.

This excessive post-operative fall in creatinine clearance was prevented in a further seven jaundiced patients by the prophylactic administration of mannitol.

In view of the high incidence of acute post-operative renal failure in decply jaundiced patients the use of prophylactic mannitol is strongly recommended.

I wish to thank all the surgeons of King's College Hospital and St. James' Hospital for allowing me to study patients under their care. This paper is an account of part of the work which was accepted as a thesis for the M.S. degree in the University of London. I am especially indebted to Mr. J. B. Woods, chief technician, 
Biochemistry Laboratory, St. James' Hospital, London, who carried out all the biochemical investigations.

\section{REFERENCES}

Abramson, H. A. (1926). Arch. intern. Med., 37, 291.

Aird, I. (1953). In The Management of Abdominal Operations, edited by $R$. Maingot. Lewis, London.

Barry, K. G., and Malloy, J. P. (1962). F. Amer. med. Ass., 179, 510.

Braun, W. E., and Lilienfield, L. S. (1962). F. clin. Invest., 41, 1347.

Brod, J. (1953). Acta med. Acad. Sci. hung., 4, 369.

- and Sirota, J. H. (1948). F. clin. Invest., 27, 645.

Cattell, W. R., and Birnstingl, M. (1964). Brit. F. Surg., 51, 72.

Clairmont, P., and Von Haberer, H. (1911). Mitt. Grenzgeb. Med. Chir. 22, 159 .

Dawson, J. L. (1964a). Brit. med. 7., 1, 810.

Dawson, J. L. (1964a). Brit. med. f.,

二 and Stirling, G. (1964). Arch. Path., 78, 254.
De Wardener, H. E. (1955). Anaesthesia, 10, 18

Doolan, P. D., Alpen, E. L., and Theil, G. B. (1962). Amer. F. Med., 32,65 .

Eliahou, H. E. (1964). Brit. med. F., 1, 807.

Finckh, E. S. (1962). Lancet, 2, 330.

Habif, D. V., Papper, E. M., Fitzpatrick, H. F., Lowrance, P., Smythe, C. McC., and Bradley, S. E. (1951). Surgery, 30, 241.

Lauson, H. D., Bradley, S. E., and Cournand, A. (1944). F. clin. Invest.,

23, 381.
Robinson, J. R. (1954). Reflections on Renal Function. Blackwell, Oxford.

Selkurt, E. E., Hall, P. W., and Spencer, M. P. (1949). Fed. Proc., 8, 143.

Sevitt. S. (1959). Lancet, 2, 135

Shannon, J. A. (1935) f. clin. Invest., 14, 403.

Smith, H. W. (1943). Lectures on the Kidney. Lawrence, Kansas, Univ. of Kansas Division.

Steinitz, K., and Türkand, H. (1940). 7. clin. Invest., 19, 285.

Williams, R. D., Elliott, D. W., and Zollinger, R. M. (1960). Arch. Surg., 81, 334.

Zollinger, R. M., and Williams, R. D. (1956). Surgery, 39, 1016.

\title{
Hospital Infection with Pseudomonas pyocyanea: An Investigation by a Combined Pyocine and Serological Typing Method*
}

\author{
A. H. WAHBA, $†$ PH.D., M.B., B.CH., D.T.M.\&H., DIP.BACT.
}

Brit. med. F., 1965, 1, 86-89

It is probable that Ps. pyocyanea has always been an important human pathogen, but many workers believe that it now causes more infections in hospitals than formerly (Forkner et al., 1958 ; Finland et al., 1959 ; Barber, 1961). A pyocine typing method was recently introduced (Wahba, 1963 ; Darrell and Wahba, 1964) to study the epidemiology of Ps. pyocyanea in hospitals. It is fairly simple to perform, but has the disadvantage that only 11 types can be distinguished. Habs (1957) showed that the serological typing of Ps. pyocyanea was practicable if suitable methods were used for the preparation of the sera. In an attempt to increase the number of recognizable subdivisions of the organisms a slide-agglutination technique of serological typing was investigated in parallel with pyocine typing.

\section{Materials and Methods}

Strains.-The two typing methods were used on 1,899 cultures of Ps. pyocyanea from a variety of sources. They included collections isolated from patients in a large number of different hospitals in the United Kingdom and in 12 other countries, as well as strains isolated from the hospital environ-

* This paper formed part of a thesis approved by the University of London for the degree of Ph.D.

+Cross-Infection Reference Laboratory, Central Public Health Laboratory, London. Present address: Depar ment of Baceriolozy, Lontory, London. Present address : ment, animals, plants, water, and milk (Wahba, 1964). Among them were 305 strains isolated in the course of investigations 'in 12 wards in 10 hospitals, which are considered in greater detail.

\section{Pyocine Typing}

The strains were examined for their ability to produce bacteriocines $^{1}$ (pyocines) active against 12 indicator strains by the cross-streaking method (Wahba and Lidwell, 1963 ; Darrell and Wahba, 1964). The patterns produced by the different types were labelled by capital letters A-P and the non-typable strains by N.T. (Table I).

\section{Serological Typing}

Eighteen cultures were used for the preparation of antisera ; these comprised the 12 type strains of Habs (1957), four strains described by Véron (1961) as being subtypes of Habs's types 2 and 5, the representative strain of type 13 (Sandvik, 1960 ; Véron, 1961), and type 14 (Wahba, 1964) (see Table II). As

1 Bacteriocines are antibiotic substances known at present to be produced by 19 different bacterial genera, their characteristic feature keing that their spectrum of activity is mainly limited to other members of particular species. This property has been used for typing several groups of organisms.

\begin{tabular}{|c|c|c|c|c|c|c|c|c|c|c|c|c|}
\hline \multirow{2}{*}{ Type } & \multicolumn{12}{|c|}{ Indicator Strain } \\
\hline & M 8 & B 10 & S 17 & B 26 & B 39 & A 52 & $8 / 39$ & $10 / 55$ & H 1180 & M 283 & H 323 & E 826 \\
\hline $\begin{array}{l}\text { A } \\
\text { B } \\
\text { C } \\
\text { D } \\
\text { F } \\
\text { G } \\
\text { K } \\
\text { L } \\
\text { O } \\
\text { P } \\
\text { N.T. }\end{array}$ & $\begin{array}{l}+ \\
+ \\
+ \\
+ \\
+ \\
\pm \\
= \\
+ \\
\pm\end{array}$ & $\begin{array}{l}+ \\
\pm \\
\pm \\
+ \\
+ \\
+ \\
\pm \\
= \\
=\end{array}$ & $\begin{array}{l}+ \\
+ \\
+ \\
+ \\
+ \\
+ \\
= \\
= \\
=\end{array}$ & $\begin{array}{l} \pm \\
\pm \\
\pm \\
= \\
= \\
= \\
=\end{array}$ & $\begin{array}{l}+ \\
+ \\
+ \\
+ \\
+ \\
+ \\
+ \\
\pm \\
-\end{array}$ & $\begin{array}{l}+ \\
+ \\
+ \\
+ \\
+ \\
+ \\
\pm \\
\pm \\
-\end{array}$ & $\begin{array}{l}+ \\
+ \\
+ \\
+ \\
+ \\
+ \\
+ \\
\pm \\
+\end{array}$ & $\begin{array}{l} \pm \\
\pm \\
\pm \\
= \\
= \\
= \\
= \\
=\end{array}$ & $\begin{array}{l}\bar{z} \\
\bar{z} \\
\bar{z} \\
\bar{z} \\
\bar{z}\end{array}$ & $\begin{array}{c}+ \text { or }- \\
+ \text { or } \\
\overline{-} \\
= \\
= \\
= \\
= \\
= \\
=\end{array}$ & $\begin{array}{l}+ \\
\pm \\
- \\
\pm \\
\pm \\
\pm \\
= \\
=\end{array}$ & $\begin{array}{l} \pm \\
\pm \\
+ \\
+ \\
\pm \\
\pm \\
\pm \\
=\end{array}$ \\
\hline
\end{tabular}

